\title{
QUANTITATIVE ACCOUNT OF THE NON-SLAVIC POPULATION OF THE SOUTH OF RUSSIA IN THE SECOND HALF OF THE $19^{\text {th }}$ CENTURY
}

\section{Irina V. Lidzieva (a), Ekaterina N. Badmaeva (b)}

(a) Federal Research Centre The Southern Scientific Centre Of The Russian Academy Of Sciences. Rostov-on-Don, Russia. Email: irina-lg[at]yandex.ru

(b) Kalmyk State University named after B.B. Gorodovikov. Elista, Russia. Email: en-badmaeva[at]yandex.ru

\begin{abstract}
The Russian state continued, in relation to the non-Slavic population of its southern periphery in the XIX century, to pursue its integrative policy, the intensity of which was largely due to the geopolitical arrangement of forces in the region, as well as to the degree of stability of the local management system and the stance of the local elite. One of the important indicators of the integration of the territory into the imperial space was possessing information about the size of its population by the imperial administration. The purpose of the study is to identify, on the basis of analyzing the documents from the funds of the State Archive of the Astrakhan Region, the State Archive of the Stavropol Territory and the National Archive of the Republic of Kalmykia, as well as the achievements of other researchers, the methods of accounting for the number of nomadic peoples, using the example of Kalmyks, Turkmens and Nogais. The study revealed that three main stages can be distinguished in the policy of accounting for the nomadic population of the southern outskirts of the Russian Empire, the main feature of each of which is the way of collecting information: that is, statistical, metric, and demographic. The first method is related to the formation of a reporting institute of foreign directorates. The second method which was the metrics, left to the clergy, was not considered the systematic and reliable data. Conducting censuses of the population (family lists, countermarks) testified to the establishment of demographic accounts in nomadic societies of the southern periphery of the Russian Empire.
\end{abstract}

Keywords

South of Russia; empire; nomadic foreigners; metric account; statistical account; demographic account; population census; kibitochnye lists; family lists; integration

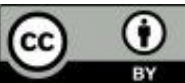

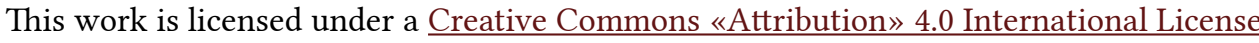




\section{КОЛИЧЕСТВЕННЫЙ УЧЕТ ИНОРОДЧЕСКОГО НАСЕЛЕНИЯ ЮГА РОССИИ ВО ВТОРОЙ ПОЛОВИНЕ ХІХ В.}

\section{Лиджиева Ирина Владимировна (a), Бадмаева Екатерина Николаевна (b)}

(а) Федеральный исследовательский центр Южный научный центр Российской академии наук. Ростов-на-Дону, Россия. Email: irina-lg[at]yandex.ru

(b) Калмыцкий государственный университет им. Б.Б. Городовикова. Элиста, Россия. Email: en-badmaeva[at]yandex.ru

\section{Аннотация}

Российское государство в отношении инородческого населения южных своих окраин в XIX в. продолжало проведение интегративной политики, интенсивность мероприятий которой во многом была обусловлена геополитической расстановкой сил в регионе, а также степенью устойчивости управленческой системы на местах и состоянием местной элиты. Одним из важных показателей интеграции территории в общеимперское пространство является владение имперской администрацией информацией о численности ее населения. Целью исследования является выявление, на основе анализа документов из фондов Государственного архива Астраханской области, Государственного архива Ставропольского края и Национального архива Республики Калмыкия, а также достижений других исследователей, способов учета численности кочевых народов, на примере калмыков, туркмен и ногайцев. В ходе исследования было выявлено, что в политике учета кочевого населения южных окраин Российской империи можно выделить три основных этапа, основным признаком каждого из которых является способ сбора информации: статистический, метрический и демографический. Первый способ связан со становлением института отчетности инородческих управлений. Второй способ метрический, возложенный на духовенство; он не отличался систематичностью и достоверностью данных. Проведение переписей населения (посемейные списки, контрамарки) свидетельствовали о налаживании демографического учета в кочевых обществах южных окраин Российской империи.

\section{Ключевые слова}

Юг России; империя; кочевые инородцы; метрический учет; статистический учет; демографический учет; перепись населения; кибиточные списки; семейные списки; интеграция

Это произведение доступно по лицензии Creative Commons «Attribution» («Атрибуция») 4.0 Всемирная 


\section{ВВЕДЕНИЕ}

В первой четверти XIX в. имперские законодатели классифицировали инородческое население, к которому, согласно трактовке, данной в словаре Брокгауза и Ефрона, относились подданные неславянского происхождения, исходя из принципа ведения хозяйства на следующие группы: оседлые, кочевые и бродячие. К кочевым народам были отнесены те, которые занимали определенные территории в зависимости от времени года (ПСЗ РИ I, 1830 b). На степных просторах южной окраины Российского государства на протяжении ряда столетий обосновались ногайцы, калмыки и туркмены, ведущие кочевой образ жизни, о численности которых органы власти имели весьма приблизительное представление. Между тем данная количественная категория в государственном масштабе имела стратегическое значение, так как была тесно связана с фискальными, военными и управленческими потребностями имперской администрации. Интерес к изучению проблемы учета численности кочевых инородцев можно проследить как при анализе дореволюционной (Страхов, 1810; Костенков, 1868; Попов, 1839; Фарфоровский, 1909) и советской историографии (Бурчинова, 1980, 1989; Калмыков, 1988; Курбанов, 1989) так и при характеристике работ современных исследователей (Авлиев, 2013; Аджиниязова, 2017; Кидирниязов, 2014; Лиджиева, 2017; Сыздыкова, 2018). Однако предметом их изучения, прежде всего, выступали количественные показатели, характеризующие численность населения, а также причины их колебания. В рамках данной статьи целью исследования является выявление способов учета численности кочевых народов, населявших южные окраины Российской империи в XIX в.

\section{МЕТОДЫ}

Разработка данной проблемы основана на использовании исследовательского инструментария социальной истории. Так, использование проблемно-хронологического метода позволило рассмотреть процедуру сбора информации о численности населения в кочевых обществах во временном порядке. С помощью применения идеографического метода стало возможно описать процесс сбора данных; на основе историко-типологического метода - провести классификацию сбора информации о численности кочевников на Юге России. 


\section{РЕЗУЛЬТАТЫ}

В первой половине XIX в. стала формироваться нормативная правовая база, регулирующая процесс жизнедеятельности упомянутых народов в рамках юридического пространства Российской империи. Диспозиции правовых норм данных законодательных актов не содержали конкретного указания на ведение количественного учета населения. Так, в соответствии с § 27 высочайше утвержденными Правилами для управления калмыцким народом 1825 г. Комиссии калмыцких дел как органу областного управления вменялось в обязанность составление списков светских и духовных феодалов. В отношении же непривилегированного населения следовало «иметь настоящее, хотя перечневое сведение о числе кибиток в каждом улусе ... не допуская, однако, переписки или ревизии» (ПСЗ РИ I, 1830 с). Фактически без изменения эта норма была перенесена в следующий нормативный правовой акт - Положение об управлении калмыцким народом 1835 г., с единственной поправкой на возложение этой функции на улусных попечителей, которые были обязаны иметь точнейшие по возможности сведения, но также без проведения переписи или ревизии (ПСЗ РИ II, 1836). Исходя из положений приведенных законодательных актов, предоставление сведений нойонами и зайсангами о численности подвластных им простолюдинов в начале XIX в. имело приблизительный характер. Так, по данным, приведенным главным приставом калмыцкого народа Н. И. Страховым, в 1803 г. калмыцкие владельцы показали о наличии у них 14198 кибиток или семейств, «но означенное число неверно, потому что калмыки от суеверия почитают за грех объявлять настоящее число имения, а из опасения чтобы не подпасть счету людей и по них налогам, скрывают рачительно свое народосчисление» (1810, с. 17-18). Как отмечает Т. Г. Борджанова, у калмыков существовала табуация чисел - передача числительных описательным путем (1999, с. 14). Суть «суеверия», по утверждению Э. П. Бакаевой, заключается в том, что «свойство исчисляемости в традиционных преставлениях калмыков определяется как признак конечности, что обусловило появление запрета на счет таких объектов, как звезды, люди, домашние животные, пища» (2009, с. 15). Подобные практики существовали у скотоводов Центральной Азии и Швеции. Архаические представления заключались в том, что существуют вещи, которые можно посчитать, и те, которые нельзя. Практика сокрытия реальных сведений о числе скота у калмыков сохраняется и в настоящее время (Тюхтенева, 2017). 
Спустя четверть века с момента опубликования сведений главным приставом Н. И. Страховым ситуация не изменилась. В 1838 г. ординарный профессор Казанского университета А. В. Попов во время путешествия по Калмыцкой степи обратил внимание, что, согласно официальным данным, численность калмыцкого населения не составляет более 13000 кибиток; при этом как отмечает он,

\begin{abstract}
«это число едва ли не вдвое уменьшенное против настоящего. Впрочем, местное начальство до сих пор не может сделать точной народной переписи по причине обширного пространства степей и беспрестанных перекочевок калмыков. Владельцы же и зайсанги, заведывающие Казенными Улусами, может быть и с намерением утаивают подлинное число своих подвластных, чтобы менее платить в Казну положенного сбора на содержание Калмыцкого Управления» $(1839$, с. 27).
\end{abstract}

Проблеме учета населения посвящен раздел III Положения об управлении калмыцким народом 1847 г., глава III которого «О обязанностях по народоисчислению» содержит гипотезу правовой нормы - сокрытие числа кибиток или семейств простолюдинов со стороны нойонов-владельцев. Санкцией в данном случае выступает перевод утаенных кибиток из владельческого улуса в статус казенного. В случае наличия факта сокрытия в казенном улусе его правитель облагался штрафом в пользу общественного капитала, если же сокрытые кибитки принадлежали аймаку родового зайсанга, то они переводились в другие аймаки того же улуса. Норма о запрете проведения переписи или ревизии сохраняла свою силу и в данном «Положении»; между тем оно конкретизировало способ сбора информации - «чрез владельцев, опекунов и Правителей улусных» (ПСЗ РИ II, 1848). В свою очередь, как утверждает Л. В. Бурчинова, которая провела анализ судебных дел об утайке нойонами и зайсангами подвластных калмыков, их информировали аймачные зайсанги и старшины (1980, с. 91). Единицей измерения численности населения служила кибитка, а в ней условно: две души мужского пола и две женского. Данный способ учета кочевого населения получил название - «кибиточные списки» и имел один большой недостаток, ставший следствием отсутствия четких требований при их составлении. Так, Л. С. Бурчинова пришла к выводу о том, что единица подсчета в разных улусах понималась по-своему. Например, в Яндыковском и Харахусовском улусах кибитка - это семейство женатого калмыка. Но в Яндыковском улусе из списка исключались сироты и одиночки, жившие самостоятельно или в семье родственников и не имевшие на момент переписи собственного хозяйства. В Эркетеновском улусе 
это каждый калмык, живший отдельной кибиткой, вне зависимости от возраста, дееспособности и имущественного положения (1980, с. 91). Относительно способа и результатов такого учета населения К. И. Костенков писал:

«Это постановление было весьма приятно лицам, стоявшим близко к управлению народом.... Правительство довольствовалось только теми сведениями, какие были доставляемы ...» (1868, с. 107).

«Положение» 1847 г. завершало создание системы управления калмыцким народом и, по мнению авторов фундаментальной «Истории Калмыкии с древнейших времен до наших дней», «побудило власти вплотную заняться учетом населения Калмыцкой степи» (2009, с. 528). Исследователь демографической истории калмыцкого народа Л.В. Оконова также считает, что, несмотря, на государственное значение процедуры установления численности населения кочевых обществ, данная проблема решалась только после определения их статуса и выработки методов управления, что и обусловило отсутствие какой-либо систематичности в сборе сведений о населении вновь присоединенных к России территорий (2015, с. 468). В более широком масштабе активность имперской администрации в рассматриваемом направлении зависела от степени интеграции народа в общеимперское пространство. Как считает М. Ходарковский, «неуклюжие действия России в первой половине XVIII в. ... показали, что пока граница остается прозрачной, прямое управление калмыками невозможно» (2019, с. 208), что подтверждает наличие не прямого, но косвенного влияния внешнеполитического фактора в рассматриваемом мероприятии.

Несколько иная ситуация сложилась в кочевых обществах Ставропольской губернии: ногайцев и трухмен. Так, Устав для управления нагайцев и других магометан, кочующих в Кавказской области, высочайше утвержденный в 1827 г., содержит единственное положение, касающееся учета населения и отраженное в $§ 78$, которое гласит:

«Раскладка повинностей и сборов в народе по введенному порядку должна падать не на число душ в кибитке, или семействе, а на имущество, т. е. скотоводство, или промысел» (ПСЗ РИ ІІ, 1830 a).

В данном случае не затрагивается проблема учета численности населения, а речь идет о налоговой базе, основой которой выступает скот. Между тем, как показывает анализ документальных материалов из фондов Государственного архива Ставропольской губернии, несмотря на преимущественное значение количества скота, формы 
запросов содержали и требование об указании численности населения. Так, например, главноуправляющий гражданской частью и пограничными делами Грузии, Армянской области, Астраханской губернии и Кавказской области, барон Г. В. Розен в 1836 г. направляет двух чиновников особых поручений к Главному приставу магометанских народов, обитающих в Кавказской области, с целью «собрания нужных сведений о всех состоящих в управлении Вашем [главного пристава - авторы] племенах», в том числе «Какое число кибиток составляет каждый род особо?» (ГАСК, 1837, л. 1). Следующий документ - рапорт частного пристава калаусо-джембулуковских ногайцев на имя главного пристава кочующих магометан Ставропольской губернии от 10 января 1846 г. свидетельствует об установлении формы отчетности, включающей сведения о численности находящегося в его ведомстве населения (ГАСК, 1835, л. 1). Подтверждением последнего служит циркуляр главного пристава кочующих народов от 12 ноября 1858 г. содержащий указание турхменскому приставу

«о срочном предоставлении статистического подробного сведения (по указанной форме) о состоянии и переменах по вверенному Вам приставству, если не точное, то, по крайней мере, приблизительное число» (ГАСК, 1858, л. 31, 38).

Приказ частного пристава, данный старшине Соин-Аджиева рода трухменского народа, гласит: «доставить ко мне непременно через два дня самые вернейшие сведения о числе народонаселения, количестве скотоводства и прочее, по примеру прежних лет» (ГАСК, 1858, л. 32). Из документа следует, что первоначальный сбор сведений осуществлялся выборными должностными лицами.

Сведения о духовенстве предоставлялись отдельными отчетами. Так, например, буддийское духовенство Большедербетовского улуса предоставляло сведения о числе хурулов на территории улуса и численности священнослужителей. Кроме того форма отчета содержала таблицы, куда необходимо было внести информацию о количестве разного вида скота, в том числе проданного в течение года (НАРК, 1868, л. 6, 7).

Несмотря на относительность количественных показателей относительно численности кочевых обществ на Юге России в первой половине XIX в., следует считать, что именно в этот период происходит формирование системы отчетности, послужившей становлению систематического учета населения, характеризуемого получением регулярных данных о численности и составе населения. 
Следующий способ определения численности населения это метрический учет на основе официальных записей актов гражданского состояния. Становление данной системы в Российском государстве связано с указом Петра I от 14 апреля 1702 г. «О подаче в Патриарший Духовный Приказ приходским священникам недельных ведомостей о родившихся и умерших» (ПСЗ РИ І, 1830 а). На протяжении первой четверти XIX в. издавались указы Святейшего Синода относительно порядка ведения метрических записей. Окончательное законодательное установление формуляра метрической книги состоялось в соответствии с указом Николая I от 7 февраля 1838 г. «О ведении метрических книг по новым формам» (ПСЗ РИ II, 1838). Данная нормативная база регулировала метрический учет православного населения империи. В отношении же мусульман 21 сентября 1828 г. был издан указ «О введении в употребление метрических книг по Оренбургскому Духовному Магометанскому Управлению» с оговоркой «для магометан ведомства Оренбургского Духовного Собрания ... сие распоряжение не было распространяемо на Таврических магометан» (ПСЗ РИ II, 1830 b). Регистрация мусульман Таврической губернии осуществлялась на основе указа 1832 г., при этом запись велась на арабском языке. Но под действие двух последних законодательных актов, по утверждению Д. М. Усмановой, не попадали мусульмане Ставропольской губернии, Терской и Кубанской областей $(2015$, с. 124$)$, т.е. в том числе относящиеся к кочевым магометанам Ставропольской губернии.

Имперский законодатель обошел своим вниманием вопрос об установлении метрического учета буддийского населения. Главный попечитель калмыцкого народа И. С. Картель по этому поводу выразил следующее мнение: «Установление метрических записей калмыцкого населения, при кочевом образе жизни и сложившихся бытовых условиях, несомненно, представляет много затруднений, практически едва ли устранимых» (ГААО, 1891, л. 9 об.).

Впервые вопрос о ведении метрических книг был возбужден главным попечителем калмыцкого народа М. И. Тагайчиновым. Метрические книги - это совокупность актов культовой регистрации, удостоверяющих события рождения, брака, смерти конкретных лиц в виде хронологических записей в книжной форме (Антонов, 1996, c. 20). Решение о постановке метрического учета калмыцкого населения затянулось на десятилетия, и только в 1873 г. ведение метрических записей закономерно было возложено на ламаистское духовенство (НАРК, 1858, л. 47). Следует отметить, что, к сожалению, примера такой записи, датированной XIX в., в фондах Национального архива 
Республики Калмыкия выявить не удалось. Между тем авторы располагают копиями документов начала XX в., например, «Метрическая книга о родившихся в ю.ч. [южной части - авторы] Малодербетовского улуса калмыках всех сословий, выданная из Управления калмыцким народом начальнику (бакши) VI Дорджид Рацынг большого хурула на 1904 год» (НАРК, 1904). Метрическая книга о родившихся калмыках была создана по аналогии с православными метрическими книгами. Так, книга форматом А4 состояла из табличных форм, расчерченных вручную или отпечатанных типографским способом, причем название каждой графы оформлялось на русском и калмыцком языках и содержала следующую информацию: дату рождения как по григорианскому календарю, так и по калмыцкому; имя родившегося; имя, фамилия, улус, род и аймак родителей; когда, на каком урочище и кем совершен над новорожденным установленный религиозный обряд и дано имя, а также личные данные двух свидетелей, удостоверяющих факт рождения ребенка (НАРК, 1904, л. 1 об-2).

Главный попечитель калмыцкого народа, действительный статский советник И. С. Картель, признавая установление метрических записей ламаитов, населяющих Астраханскую губернию, «весьма полезным и необходимым для нужд управления», в рапорте астраханскому губернатору А. Г. Бринкману от 18 декабря 1891 г. выразил сомнения по поводу качества исполнителя столь важного для государства дела,

«ибо калмыки приглашают духовных лиц дать молитву новорожденному, помолиться за новобрачных, а также лечить больных, напутствовать умирающих, но так как подобные приглашения в сильной мере зависят от степени религиозного усердия нуждающихся в том лиц и от их экономического благосостояния, то часто случается, что калмык небогатого достатка, кочуя далеко от хурула (ламайский монастырь), или совсем не сообщает духовенству в случаях рождения, бракосочетания и смерти коголибо из членов своей семьи, или же сообщают об этом как-нибудь после, при удобном случае, например, тогда как прикочуют к хурулу» (ГААО, 1891, л. 10).

По словам Пола Верта, перевод функции ведения метрического учета на духовенство свидетельствовал об административной слабости имперского государства, чье стремление к всеобщей регистрации населения удавалось лишь косвенно, чрез посредничество религиозных служащих и институтов (2012, с. 117-143).

В 1891 г. вопрос о необходимости введения метрических записей вновь актуализировался в связи с отношением казанского губернатора 
о способе учета языческого населения, поданным в министерство внутренних дел, где он отмечает, что ведение метрических записей для лиц как христианского, так и мусульманского исповедания имеет законодательное регулирование, а относительно «язычников указаний не имеется» (ГААО, 1891, л. 1). По его мнению, посемейные списки, основанием которых должны служить метрические записи, не могут заменить последние, так как они составляются один раз в год и дают сведения о числе наличных жителей, но не могут с точностью представить движение населения в хронологическом и количественном отношении. В связи с этим запросом Центральный статистический комитет, по приказанию министра, обратился к астраханскому губернатору с просьбой сообщить, «каким порядком производится регистрация сего населения и вообще Ваше заключение по вопросу об установлении в законодательном порядке узаконений для производства метрических записей при регистрации языческого населения» (ГААО, 1891, л. 1 об.). Составление ответа на данный запрос было поручено главному попечителю калмыцкого народа С. И. Картелю, который в своем рапорте за № 3753 от 26 августа 1891 г., направленному астраханскому губернатору сообщает, что

«движение населения в калмыцких степях Астраханской губернии до сего времени регистрировались на точном основании порядка указанного § 199 Положения об управлении калмыцким народом, т. е. периодически через каждые 10-12 и более лет составлялись семейные списки калмыков, причем на основании того же §, никакой переписи или ревизии по форме не производилось, равным образом и ввиду того же § никаких метрических записей и книг калмыкам до сего времени не велось» (ГААО, 1891, л. 6).

Позднее, 18 декабря 1891 г., И.С. Картель направляет губернатору свои предложения в разрешении вопроса по предмету учета калмыцкого населения, акцентируя внимание на том, что буддийское духовенство не может быть эффективным исполнителем метрического учета. Кроме того, по его мнению,

«вообще не представляется желательным давать ламайскому духовенству такие правительственные поручения, которые возвышали бы его значение среди народа» (ГААО, 1891, л. 9 об.).

Следует отметить, что подобная ситуация сложилась и в отношении мусульманского населения. Так, создание мусульманских религиозных институтов и официально признание за муллами определенных судебно-административных прав стало восприниматься (как миссионерами, так и отдельными чиновниками) как мера, хотя и 
вынужденная, но в целом нежелательная, так как привела к чрезмерному росту значимости духовенства в жизни мусульманского общества (Усманова, 2015, с. 127).

В этом же рапорте И.С. Картель предлагает поручить ведение записей всех семейств с отметками всех умерших, родившихся и вступивших в брак аймачным или родовым зайсангам, старшинам и опекунам, снабдив их специальными книгами. Запись в книгах могла вестись как на русском языке, так и на калмыцком. В случае неграмотности указанных лиц они могли воспользоваться услугами грамотных однообщественников. Для предотвращения злоупотреблений или исправления упущений предлагалось проведение на аймачных или родовых сходах один раз в год сверки в присутствии улусного попечителя. Сведения об изменении численности населения на подведомственных данным должностным лицам территориях предполагалось ежегодно направлять в улусные управления. Установление данного порядка ведения метрических записей могло быть произведено после проведения переписи калмыцкого народа, которая диспозицией правовой нормы параграфа 199 «Положения об управлении калмыцким народом» запрещалась. В заключительной части рапорта главный попечитель И. С. Картель отмечает, что «данный способ не принесет точных результатов, тем не менее, приблизит это дело к желаемой цели и установит, конечно, не без упущений, хронологическую последовательность в численных изменениях калмыцкого народа» (ГААО, 1891, л. 10).

В направленном 31 декабря в Центральный Статистический Комитет письме А. Г. Бринкман дословно приводит предложения главного попечителя калмыцкого народа, при этом добавляя:

«я со своей стороны полагал бы более удобным и целесообразным производство метрических записей в калмыцкой степи возложить на ответственную обязанность ламайского духовенства, которое имеет возможность исполнить эту обязанность гораздо успешнее других лиц» (ГААО, 1891, л. 14).

В целях получения более достоверных сведений, характеризующих демографическое положение в Калмыцкой степи, и устранения погрешностей вследствие составления кибиточных списков, в 1856 г. чиновником Министерства государственных имуществ Г. Любовидским предлагалось проведение «негласной домашней переписи» (Бурчинова, 1980, с. 91). В 1861 г. Министерство государственных имуществ, поддержав предложение Г. Любовидского, дало разрешение Главному попечителю калмыцкого народа произвести учет населения 
путем составления списков, впоследствии получивших название «семейные» или «посемейные». На каждую семью простолюдина составлялся список, где указывались имя и фамилия ее главы, состав, степень состоятельности и местопребывание. Также подлежали регистрации одинокие, больные, старые и несовершеннолетние.

По определению К. И. Костенкова, для достижения более удовлетворительных результатов в 1862 г. были введены контромарки, в которые вносились сведения об улусе, аймаке, где числился калмык, имя, фамилия и № кибитки по семейному списку (1868, с. 108). 22 февраля 1864 г. результаты переписной кампании были доложены Министерству государственных имуществ. Полученные сведения, характеризующие количественные и половозрастные характеристики калмыцкого народа Астраханской губернии, обусловили становление демографического учета в Калмыцкой степи.

Необходимость получения актуальных данных о численности податного населения обусловило проведение в 1868 г. новой переписи калмыцкого народа. Посемейный учет калмыков велся в специальной книге форматом А4, в табличной форме, состоящей из девяти граф: 1 графа - №№ по порядку; 2 графа - №№ по семейному списку; 3 графа - название рода - аймака - хотона и прозвание родоначальников и всех членов семейств, мужчин и одиночек; 4 графа - число лет по 1 января 1869 г; 5 графа - род занятий; 6 графа - количество скота: верблюдов лошадей, рогатого скота, овец, коз, свиней; 7 графа - имена и прозвания членов семейств женского пола, вдов и сирот; 8 граффа полных лет к 1 января 1869 г.; 9 графа - примечание (НАРК, 1837, л. 6 об.-7). Название каждой графы прописывалось на русском и калмыцком языках.

Следующую санкцию на производство учета населения Управление калмыцким народом получило 16 июня 1876 г. от высшего совещательного и распорядительного органа империи - Комитета министров, в соответствии с которой предполагалось в следующем году проведение сверки семейных списков, составленных ранее, т. е. в 1868 г.

Процедура сбора сведений происходила на уровне чиновников улусных управлений, т.е. попечителей и их помощников, которые в соответствии с запросом Главного управления калмыцким народом направляли актуальные списки калмыков. Так, с целью исполнения предписания от 24 августа 1876 г. за № 4073, в декабре 1876 г. попечитель Икицохуровского улуса направляет в Главное Управление калмыцким народом семейные списки аймачных и безаймачных зайсангов и калмыков-простолюдинов, составленные в 1876 г. 
При этом достоверность направляемых сведений подтверждалась приговором общества калмыков Икицохуровского улуса (НАРК, 1876, л. 2). Улусный сход состоялся 10 декабря 1876 г. в зимней ставке Икицохуровского улуса, где поверяли вновь составленные в ноябре 1876 г. семейные списки калмыков названного улуса. В заключительной части приговора значится, что «списки о зайсангах и калмыках простолюдинах составлены верно» (НАРК, 1876, л. 4 об.).

Улусные попечители, кроме учета населения, находящегося на подконтрольной им территории, отслеживали местопребывание тех калмыков, которые временно проживали вне улуса, - путем осуществления переписки с присутственными местами и должностными лицами Астраханской и соседних губерний. На основе полученных сведений составлялись сводные списки, которые существовали в одном экземпляре и ежегодно запрашивались Управлением калмыцкого народа. Так, например, в декабре 1876 г. в сопроводительном письме к указанным сведениям на имя Главного попечителя калмыцкого народа заведующий Икицохуровским улусом С. Е. Матвеев просит «по миновании надобности их возвратить ко мне» (НАРК, 1876, л. 1).

Подобная сверка семейных списков проводилась более чем через десять лет в 1888 г., что было обусловлено потребностью имперских органов в точной информации о численности калмыков, в большей степени для фискальных нужд. Перепись осуществлялась путем заполнения табличной формы ведомости, такой же, как и в 1868 г., но выполненной литографическим способом (НАРК, 1876, л. 12 об.-13). Следует отметить, что «домашними» переписями были охвачены только калмыки Астраханской губернии, так как Большедербетовский улус императорским указом 1859 г. был введен под юрисдикцию главного пристава кочующих народов Ставропольской губернии (Лиджиева, 2015, с. 16).

Первая Всероссийская перепись населения 1897 г. позволила получить наиболее полные сведения о численности калмыцкого народа. Основные группы калмыков проживали в Астраханской и Ставропольской губерниях, а также в Области Войска Донского. Позднее налаживался учет отдельных категорий групп населения. Так, например, в 1916 г. Центральным статистическим комитетом Министерства Внутренних Дел проводился сбор сведений о сиротах, полу-сиротах и беспризорных детях до 12 лет. Как и ранее, первичный сбор данных осуществлялся выборными должностными лицами местного самоуправления путем заполнения формы отпечатанной типографским способом (НАРК, 1916, л. 30). 


\section{ВЫВОДЫ}

Таким образом, на протяжении XIX столетия имперская политика в отношении учета численности кочевых инородцев Юга России претерпевала значительные изменения в части способов и методов получения информации, но с сохранением основной цели - установления достоверных сведений, продиктованной потребностями полной интеграции кочевников в общероссийское пространство. Исходя из обозначенного вектора внутренней политики, имперская администрация стремилась действовать в отношении инородческого населения, обитавшего на окраинных территориях государства, в зависимости от геополитической расстановки сил в регионе, а также от степени устойчивости управленческой системы на местах и состояния местной элиты. В связи с этим в политике учета кочевого населения южных окраин Российской империи можно выделить три основных этапа, основным признаком каждого из которых является способ сбора информации: статистический, метрический и демографический. Первый способ связан со становлением института отчетности инородческих управлений. Второй способ - метрический, возложенный на духовенство, не отличался систематичностью и достоверностью данных. Проведение переписей населения (посемейные списки, контрамарки) свидетельствовали о налаживании демографического учета в кочевых обществах южных окраин Российской империи.

\section{БЛАГОДАРНОСТИ}

Публикация подготовлена в рамках реализации Государственного задания Федерального исследовательского центра Южного научного центра РАН, № гр. проекта АААА-А19-119011190 182-8.

\section{Список литературы}

Авлиев, В. Н. (2013). Динамика численности калмыков в последней четверти XIX в.

(На материалах Малодербетовского улуса Калмыцкой степи Астраханской губернии. Вестник Калмыцкого университета, (1), 50-55.

Аджиниязова, А. К. (2017). Территория расселения и численность ногайцев Северного Кавказа в конце XVIII - середине XIX в. Историческая и социальнообразовательная мыслль, 9(6/2), 57-58. doi: 10.17748/2075-9908-2017-9-6/2-53-58

Антонов, Д. Н., \& Антонова, И. А. (1996). Метрические книги: Время собирать камни. Отечественные архивы, (4), 15-28. 
Бакаева, Э. П. (2009). «Двадцать копеек - это семьдесят денег». Этнографическое обозрение, (2), 13-16.

Борджанова, Т. Г. (1999). Магическая поэзия калмыков. Элиста: Калмыцкое книжное издательство.

Бурчинова, Л. С. (1980). Источниковедческие вопросы изучения истории Калмыкии. (Вторая половина XIX в.). Элиста: Калмыцкое книжное издательство.

Бурчинова, Л. С. (1989). Повинности калмыцкого крестьянства в период утверждения капитализма в России (60-е и начало 90-х годов XIX в.). В Социальноэкономическое и политическое положение крестьянства Калмыкии в дооктябрьский период (сс. 90-114). Элиста: Калмыцкий научно-исследовательский институт.

Верт, П. (2012). Православие, инославие, иноверие: Очерки по истории религиозного разнообразия Российской империи. Москва: Новое литературное обозрение.

Государственный архив Астраханской области. (1891). Ф. 1. Оп. 9. Д. 777.

Государственный архив Ставропольского края. (1835). Ф. 249. Оп. 3. Д. 2385.

Государственный архив Ставропольского края. (1837). Ф. 249. Оп. 3. Д. 2345.

Государственный архив Ставропольского края. (1858). Ф. 408. Оп. 1. Д. 1633.

История Калмыкии с древнейших времен до наших дней: В 3-х томах (Т. 1). (2009). Элиста: ГУ «Издательский дом «Герел».

Калмыков, И. Х., Керейтов, Р. Х., \& Сикалиев, А. И. (1988). Ногайцы. Историкоэтнографический очерк. Черкесск: Ставропольское книжное издательство Карачаево-Черкесское отделение.

Кидирниязов, Д. С. (2014). Расселение ногайцев Северного Кавказа в XV-XIX вв. В Ногайцыь: XXI век. История. Язык. Культура. От истории - к грядущему (сс. 4554). Карачаевск: Карачаево-Черкесский государственный университет им. У. Д. Алиева.

Костенков, К. И. (1868). Статистико-хозяйственное описание Калмыцкой степи Астраханской губернии. Санкт-Петербург: Типография В. Безобразова и компании.

Курбанов, А. В. (1995). Ставропольские трухмены. Историко-этнографические очерки. Санкт-Петербург: Издательство отделения Языкового центра СПбГУ.

Лиджиева, И. В. (2015). Большедербетовский улус: Государственное управление и общественное самоуправление в контексте административно-территориальных преобразований во второй половине XIX в. Вестник калмыцикого института гуманитарных исследований РАН, 8(3), 14-19.

Лиджиева, И. В. (2017). Перепись населения 1897 г. Как источник по истории кочевых народов Степного Предкавказья. В Социально-экономическое и политическое развитие народов Северного Кавказа (XIX - начало XXI вв.) (сс. 258262). Грозный: АО «Издательско-полиграфический комплекс "Грозненский рабочий».

Национальный архив Республики Калмыкия. (1858). Ф. И-9. Оп. 1. Д. 21. 
Национальный архив Республики Калмыкия. (1869). Ф. И-9. Оп. 3. Д. 3.

Национальный архив Республики Калмыкия. (1876). Ф. И-9. Оп. 4. Д. 311.

Национальный архив Республики Калмыкия. (1904). Ф. И-9. Оп. 2. Д. 136.

Национальный архив Республики Калмыкия. (1916). Ф. И-21. Оn. 1. Д. 333.

Национальный архив Республики Калмыкия НАРК. (1868). Ф. И-21. On. 1. Д. 83.

Оконова, Л. В. (2006). Законодательно-актовые источники XIX в. По учету населения калмыков. Научная мысль Кавказа, (3), 37-41.

Оконова, Л. В. (2015). Демографический учет калмыков в Российской империи: Его эволюция и трансформация. Исторический журнал: научные исследования, 4(28), 467-471. doi: 10.7256/2222-1972.2015.4.17024

Олчанова, Ц. В., \& Очиров, Б. В. (2020). Демографические данные о кочевых народах по данным переписи населения 1897 года. Огарев-Online, (2). Извлечено от http://journal.mrsu.ru/arts/demograficheskie-dannye-o-kochevyx-narodax-podannym-perepisi-naseleniya-1897-goda

Очиров, У. Б. (2003). К вопросу о численности этнических групп калмыков за пределами калмыцких кочевий в конце XVII-начале XX вв. Монголоведение, (3), 194-203.

Полное собрание законов Российской империи. (1830а). Т. 4. Ч. І. № 1908.

Полное собрание законов Российской империи. (1830b). Т. 38. № 29126.

Полное собрание законов Российской империи. (1830с). Т. 40. № 30290.

Полное собрание законов Российской империи II. (1836). Т.10. Прибавление к тому IX. № 7560 a.

Полное собрание законов Российской империи II. (1838). Т. 13. Ч. 2. № 10956.

Полное собрание законов Российской империи II. (1848). Т. 22. Ч. I. № 21144.

Полное собрание законов Российской империи II. (1830а). T. 2. № 878.

Полное собрание законов Российской империи II. (1830b). T. 3. № 2296.

Попов, А. В. (1839). Краткие замечания о приволжских калмыках. Санкт-Петербург: Типография Императорской Академии Наук.

Страхов, Н. И. (1810). О калмыках. Нынешнее состояние калмыцкого народа, с присовокуплением калмыцких законов и судопроизводства, десяти правил их веры, молитвы, нравоучительной повести, сказки, пословии и песни савардин. СанктПетербург: Типография Шнора.

Сыздыкова, С. Ж. (2018). К вопросу о динамике расселения и роста численности туркмен Ставропольского края. Гуманитарные, социально-экономические и общественные науки, (2), 98-100. doi: 10.23672/SAE.2018.2.11495

Тюхтенева, С. П. (2017). Одна черточка - одна сотня: К вопросу о способах подсчета скота у тюрко-монгольских народов. Вестник калмыцкого института гуманитарных исследований РАН, 10(5), 130-140. doi: 10.22162/2075-7794-2017-33-5130-140 
Усманова, Д. М. (2015). Мусульманские метрические книги в Российской империи: Между законом, государством и общиной (вторая половина XIX - первая четверть XX в.). Ab imperio, (2), 106-153. doi: 10.1353/imp.2015.0034

Фарфоровский, С. В. (1909). Ногайщы Ставропольской губернии. Историко-этнографический очерк. Тиффлис: типография К. П. Козловского.

Ходарковский, М. (2019). Степные рубежи России: Как создавалась колониальная империя. 1500-1800. Москва: Новое литературное обозрение.

\section{References}

Avliyev, V. N. (2013). Dynamics of Kalmyk Population in the Last Quarter of the 19th Century. (On the Materials of the Maloderbetovsky Ulus of the Kalmyk Steppe, Astrakhan Province). Bulletin of Kalmyk University, (1), 50-55. (In Russian).

Ajiniyazova, A. K. (2017). The Territory of Settlement and the Number of Nogai in the North Caucasus in the late 18th - mid 19th centuries. Historical and Socio-Educational Thought, 9(6/2), 57-58. doi: 10.17748/2075-9908-2017-9-6/2-53-58 (In Russian).

Antonov, D. N., \& Antonova, I. A. (1996). Metric Books: A Time to Gather Stones. National Archives, (4), 15-28. (In Russian).

Bakaeva, E. P. (2009). “Twenty kopecks is seventy money”. Ethnographic Review, (2), 13-16. (In Russian).

Borjanova, T. G. (1999). The Magical Poetry of the Kalmyks. Elista: Kalmyk Book Publishers. (In Russian).

Burchinova, L. S. (1980). Source study issues of the history of Kalmykia. (The second half of the 19th century). Elista: Kalmyk Book Publishers. (In Russian).

Burchinova, L. S. (1989). Duties of the Kalmyk peasantry during the period of the establishment of capitalism in Russia (60s and early 90s of the XIX century). In Socioeconomic and political situation of the Kalmyk peasantry in the pre-October period (pp. 90-114). Elista: Kalmyk Research Institute. (In Russian).

Werth, P. (2012). Orthodoxy, Non-Orthodoxy, and Other Beliefs: Essays on the History of Religious Diversity in the Russian Empire. Moscow: New Literary Review. (In Russian).

State Archive of Astrakhan Region. (1891). F. 1. Inv. 9. C. 777. (In Russian).

State Archive of Stavropol Region. (1835). F. 249. Inv. 3. C. 2385. (In Russian).

State Archive of Stavropol Region. (1837). F. 249. Inv. 3. C. 2345. (In Russian).

State Archive of Stavropol Region. (1858). F. 408. Inv. 1. C. 1633. (In Russian).

History of Kalmykia from Ancient Times to the Present Day: In 3 Volumes (Vol. 1). (2009). Elista: Publishing House Gerel. (In Russian).

Kalmykov, I. H., Kereitov, R. H., \& Sikaliev, A. I. (1988). Nogaytsy. Historical and Ethnographic Essay. Cherkessk: Stavropol Book Publishers Karachaevo-Cherkessky Branch. (In Russian). 
Kidirniyazov, D. S. (2014). Settlement of the Nogai in the North Caucasus in the 15th-19th centuries. In Nogays: 21st century. History. Language. Culture. From history - to future (pp. 45-54). Karachaevsk: Karachaevo-Cherkessia State University U. D. Aliev. (In Russian).

Kostenkov, K. I. (1868). Statistical and Economic Description of the Kalmyk Steppe of Astrakhan Province. St. Petersburg: Typography of V. Bezobrazov and Company. (In Russian).

Kurbanov, A. V. (1995). Stavropol Trukhmen. Historical and Ethnographic Sketches. St. Petersburg: Publishing Department of the Language Center SPbSU. (In Russian).

Lidzhieva, I. V. (2015). Bolshederbetovsky Ulus: State Administration and Public SelfGovernment in the Context of Administrative and Territorial Transformations in the Second Half of the 19th Century. Bulletin of the Kalmyk Institute for Humanitarian Research of the Russian Academy of Sciences, 8(3), 14-19. (In Russian).

Lidzhieva, I. V. (2017). The 1897 census as a source on the history of the nomadic peoples of the Steppe Pre-Caucasus. In Socio-economic and political development of the peoples of the North Caucasus (19th - early 21st centuries). (pp. 258-262). Grozny: "Groznensky Rabochiy" publishing and printing complex. (In Russian).

National Archives of the Republic of Kalmykia. (1858). F. I-9. Inv. 1. C. 21. (In Russian).

National Archives of the Republic of Kalmykia. (1869). F. I-9. Inv. 3. C. 3. (In Russian).

National Archives of the Republic of Kalmykia. (1876). F. I-9. Inv. 4. C. 311. (In Russian).

National Archives of the Republic of Kalmykia. (1904). F. I-9. Inv. 2. C. 136. (In Russian).

National Archives of the Republic of Kalmykia. (1916). F. I-21. Inv. 1. C. 333. (In Russian).

National Archives of the Republic of Kalmykia. (1868). F. I-21. Inv. 1. C. 83. (In Russian).

Okonova, L. V. (2006). Legislative-actual sources of the 19th century on the registration of the Kalmyk population. Scientific Thought of the Caucasus, (3), 37-41. (In Russian).

Okonova, L. V. (2015). Demographic Accounting of Kalmyks in the Russian Empire: Its Evolution and Transformation. Fournal of History: Research, 4(28), 467-471. doi: 10.7256/2222-1972.2015.4.17024 (In Russian).

Olchanova, C. V., \& Ochirov, B. V. (2020). Demographic data on nomadic peoples according to the 1897 census. Ogarev-Online, (2). Retrieved http://journal.mrsu.ru/arts/ demograficheskie-dannye-o-kochevyx-narodax-po-dannym-perepisi-naseleniya1897-goda (In Russian).

Ochirov, U. B. (2003). To the Question of the Number of Kalmyk Ethnic Groups Outside Kalmyk Nomadic Areas in the Late 17th-early 20th Centuries. Mongolian Studies, (3), 194-203. (In Russian).

Complete Collection of Laws of the Russian Empire. (1830a). Vol. 4. Part. I. № 1908. (In Russian).

Complete Collection of Laws of the Russian Empire. (1830b). Vol 38. № 29 126. (In Russian).

Complete Collection of Laws of the Russian Empire. (1830c). Vol 40. № 30 290. (In Russian). 


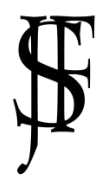

Журнал Фронтирных Исследований. 2021. No 3 | ISSN: 2500-0225

Complete Collection of Laws of the Russian Empire II. (1836). Vol10. Addition to themoмy IX vol. № 7560 a. (In Russian).

Complete Collection of Laws of the Russian Empire II. (1838). Vol 13. Part 2. № 10 956. (In Russian).

Complete Collection of Laws of the Russian Empire II. (1848). Vol 22. Part I. № 21 144. (In Russian).

Complete Collection of Laws of the Russian Empire II. (1830a). Vol 2. № 878. (In Russian).

Complete Collection of Laws of the Russian Empire II. (1830b). Vol 3. № 2296. (In Russian).

Popov, A. V. (1839). Brief Notes on the Volga Kalmyks. St. Petersburg: Printing Office of the Imperial Academy of Sciences. (In Russian).

Strakhov, N. I. (1810). About the Kalmyks. The Present State of the Kalmyk People, with an Appendix of Kalmyk Laws and Proceedings, Ten Rules of their Faith, Prayer, Moral Narrative, Tales, Proverbs, and Song of the Savardin. St. Petersburg: Schnor Printing House. (In Russian).

Syzdykova, S. J. (2018). On the dynamics of settlement and growth of the number of Turkmens of Stavropol Krai. Humanities, Socio-Economics, and Social Sciences, (2), 98-100. doi: 10.23672/SAE.2018.2.11495 (In Russian).

Tyukhteneva, S. P. (2017). One Line-One Hundred: To the Question of Livestock Counting Methods among the Turkic-Mongolian Peoples. Bulletin of the Kalmyk Institute for Humanitarian Research of the Russian Academy of Sciences, 10(5), 130-140. doi: 10.22162/2075-7794-2017-33-5-130-140 (In Russian).

Usmanova, D. M. (2015). Muslim metric books in the Russian Empire: Between Law, State, and Community (second half of the 19th century to the first quarter of the 20th century). Ab imperio, (2), 106-153. doi: 10.1353/imp.2015.0034 (In Russian).

Farforovsky, S. V. (1909). Nogays of Stavropol Province. Historical and Ethnographic Sketch. Tiflis: printing house of K. P. Kozlovsky. (In Russian).

Khodarkovsky, M. (2019). Russia's Steppe Frontiers: How the Colonial Empire Was Created. 1500-1800. Moscow: New Literary Review. (In Russian). 